\title{
PRESIDENT'S REPORT FOR VOLUME 60
}

The Centennial Year 2013 has been a fantastic year for the Society. We reached our 100th birthday as a Society on April 13, 2013. To celebrate the achievement of this milestone, we held a symposium in Berkeley on Saturday, April 14, hosted a special celebratory banquet that evening, and held the symposium in conjunction with the 23rd graduate student meetings on Sunday, April 15. We published an article in Fremontia (the Bulletin of the California Native Plant Society, 40:7-10) highlighting the history of the Society and contributions to California botany. We also conducted a series of field trips in honor of the 100th birthday. Brent Mishler led a bryology foray to the Cobb Mountain Region (March 2012), Dave Keil and Matt Ritter led a field trip to Fort Ord (May 2012), Tom Parker and Mike Vasey led a field trip to the Gold Lake Region (July 2012), and Jen Beck and Calvin Farris led a field trip to Desert Creek Natural Research Area (July 2012). For the Centennial weekend, on Friday, April 13, field trips went to Mt. Tamalpais (led by Dean Kelch with Brennan Wenck-Reilly) and Mt. Diablo (led by Barbara Ertter with Ingrid Jordon-Thaden). That Friday evening, we also enjoyed a mixer attended by over a hundred participants who renewed old acquaintances and made new ones. Our symposium linked our botanical past with the future through a series of talks led by Todd Keeler-Wolf (Cal Dept F\&G), Aaron Liston (Oregon State), Bruce Baldwin (UCB), and Dave Peterson (U. Washington and USFS Western Mountain Initiative) in the morning, followed by Anna Jacobson (CSU Bakersfield), Ray Callaway (U Montana), Carla D'Antonio (UCSB), and Richard Hobbs (U Western Australia) in the afternoon. Kent Holsinger (U Conn) provided an entertaining and informative banquet talk to wrap up this amazing day. On Sunday, more impressive talks were delivered, this time by three concurrent sessions of graduate student presentations. The graduate student meetings were supported by a number of volunteers, graduate student panel chairs, and judges. Awards were provided in several categories, always a difficult process. Ayla Mills, California State University, Chico, won for Proposed Research. Tommy Stoughton, Claremont Graduate University, won for Research in Progress. Diana Gamba, San Francisco State University and California Academy of Sciences, won for Completed Research. And finally, Jenn Yost, University of California, Santa Cruz, won for Best Talk. Please see www.calbotsoc.org for more information about the Centennial and links to or our Facebook page for photographs by Centennial photographer Brennan Wenck-Reilly and Centennial Symposium talks on YouTube by Lockyer Video Productions. Special thanks go to Genevieve Walden from UC Berkeley for her outstanding effort at organizing the graduate student meeting.

The Centennial was made possible by the generous sponsorship by the following individuals and organizations: East Bay Regional Parks District, RECON, Marin Municipal Water District, Golden Gate Parks Conservancy, Stillwater Sciences, Claremont Canyon Conservancy, WRA Environmental Conservancy, BOTANY and Rainbows, V. Thomas Parker and Alison Sanders, Northern California Botanists, Lawrence Janeway, GANDA, Heath Bartosh, Dean G. Kelch, Calflora, University and Jepson Herbaria, Michael C. Vasey and Patti Papeleux, Thomas J.
Rosatti, Steven Timbrock, Taylor Crow, Kristina Schierenbeck, Michael Williams, and an Anonymous sponsor. Thank you.

The Council's work this year has been busy and exceptionally productive. We finalized an agreement with JSTOR (an online archiving system) to place all of our Madroño back issues online and they are now available (since April, 2013). Current issues are already online through BioOne.2. We are moving toward having the current online issues easily available through individual member subscriptions, so look forward to that. One of the journal's editors, Richard Whitkus, has announced that he is stepping down after several pivotal years. We all are thankful to have had Rich during the time the journal converted to an online manuscript submission and tracking process and he also was instrumental in our rapidly catching back up on schedule. The Council has worked particularly hard this year because of the Centennial and I would especially like to thank Andrew Doran, Dean Kelch, Kim Kersh, Anna Larsen, Staci Markos, Matt Ritter, Tom Schweich, Michael Vasey, Genevieve Walden, and Rich Whitkus. We all owe them a great deal of thanks for their outstanding efforts. Our staff members, Lynn Yamashita and Bier [Ekaphan] Kraichak, also played crucial roles in the Centennial and deserve equal recognition for their efforts. Finally, the Council drafted an outsider to help with organizing details of the Centennial and to make sure we stayed on track in a timely fashion; accordingly, the Council especially thanks Alison Sanders for her role.

What does it mean for a Society to reach the age of one hundred years? Almost 300 botanists came from great distances for all or part of our three-day Centennial celebration. I think this suggests that the Society continues to provide an important resource for plant-oriented biologists in California and the western United States. The central objectives of the Society when it was established were to promote the collection of new information about the flora of the West, to provide a vehicle for disseminating that information, and to educate the public about the value of conserving plant species and habitats found in wild areas throughout our region. Clearly the Society has achieved these objectives in large measure. Nonetheless, over time, the membership has evolved and our interests overall have shifted as our science has matured. A Society is only as healthy as its membership and the engagement of that membership in the mission of the Society. We must continue to grow our membership, including its leadership, and be ready to respond to new opportunities. Advanced technologies now make it possible for us to broaden our reach and the challenge will be for us to do so over the next hundred years. Certainly, and unfortunately, the need for our science to help conserve plant resources is not diminishing but rather becoming more critical every day.

This issue of Madroño reprints a small selection of articles from the past century as a way of reminding us of the central role the California Botanical Society has played in the development of concepts about plant evolution, ecology, systematic relationships, paleohistory, biogeography, conservation management and ecological restoration. Take the opportunity to read not only this collection, but to explore the prior sixty volumes (an index is found online 
at our website). You will be rewarded by a diverse array of articles about the history of botanical exploration in the western United States and Mexico in the 18th and 19th centuries, early floras of a variety of places (including an early one of the Swiss Alps!), and arguments about the concepts on which we base our sciences. You will also see that our Society has been a critical source of creativity and innovation for plant sciences. Now it remains for the membership to continue the impressive traditions of this past century.
V. Thomas Parker December 2013 


\section{$2 \mathrm{BHL}$ Biodiversity Heritage Library}

Parker, V Thomas. 2013. "President's Report for Volume 60." Madroño; a West American journal of botany 60, 360-361.

https://doi.org/10.3120/0024-9637-60.4.360.

View This Item Online: https://www.biodiversitylibrary.org/item/202937

DOI: https://doi.org/10.3120/0024-9637-60.4.360

Permalink: https://www.biodiversitylibrary.org/partpdf/282780

\section{Holding Institution}

Smithsonian Libraries

\section{Sponsored by}

Biodiversity Heritage Library

\section{Copyright \& Reuse}

Copyright Status: In Copyright. Digitized with the permission of the rights holder License: http://creativecommons.org/licenses/by-nc/3.0/ Rights: https://www.biodiversitylibrary.org/permissions/

This document was created from content at the Biodiversity Heritage Library, the world's largest open access digital library for biodiversity literature and archives. Visit BHL at https://www.biodiversitylibrary.org. 